\title{
Manajemen Produksi dan Pemasaran Benih Padi di PT. PERTANI (Persero) Cabang Bali
}

\author{
MADE CANDRA KIRANA CAHYANINGRUM, I KETUT SUAMBA, \\ I GUSTI AYU OKA SURYAWARDANI
}

\author{
Program Studi Agribisnis, Fakultas Pertanian, Universitas Udayana \\ Jl. PB. Sudirman Denpasar 80323 \\ Email: candrakiranaa1@gmail.com \\ suamba_unud@yahoo.co.id
}

\begin{abstract}
The Production and Marketing Management of Rice Seeds at PT. PERTANI (Limited) of Bali Branch
\end{abstract}

This study aimed at determining the application of management functions in the production of rice seeds in PT. PERTANI (Limited) of Bali Branch, as well as to find out the marketing activities of rice seed conducted by PT. PERTANI (Limited) of Bali Branch. Based on these objectives, the study used qualitative descriptive analysis method. The result of the research showed that PT. PERTANI (Limited) of Bali Branch has implemented management function well in production activities. Implementation of management functions include the planning process that has been set in the Work Plan and Corporate Budget, the organizing process was set in a clear organizational structure. Monitoring process in production activities was conducted by the head of Seed Production Unit (UPB) of Munggu and team. The evaluation process was conducted every three months starting from the amount of production, the basic cost of the seeds, and the costs incurred in the production activities, and the quality of the seeds produced by PT. PERTANI (Limited) of Bali Branch that has implemented marketing mix (4P) items consisting of product, place, price, and promotion in marketing the seeds.

Keywords: seed, production management, marketing mix

\section{Pendahuluan}

\subsection{Latar Belakang}

Kebutuhan pangan adalah kebutuhan dasar manusia yang sangat penting untuk dipenuhi, sehingga kecukupan pangan bagi setiap orang harus terpenuhi dengan optimal. Permintaan akan pangan, yang merupakan kebutuhan dasar, akan terus meningkat seiring dengan perkembangan jumlah penduduk dan peningkatan kualitas hidup manusia. Usaha peningkatan ketahanan pangan serta agribisnis tidak akan berhasil tanpa penggunaan benih yang bermutu oleh petani. Benih yang bermutu adalah benih yang baik dan bermutu tinggi yang menjamin pertanaman baik dan hasil panen yang tinggi serta telah memperoleh sertifikasi oleh Balai Pengawasan dan Sertifikasi Benih Tanaman Pangan (BPSBTP). Dengan kata lain 
benih bermutu atau bersertifikat berpengaruh terhadap peningkatan produksi dan produktifitas hasil pertanian.

Ketahanan pangan dan ketersediaan benih dapat ditingkatkan melalui penggunaan benih padi bermutu dan bersertifikat, maka diperlukan upaya penangkaran benih padi yang dilakukan pemerintah, BUMN, swasta atau pengusaha benih, balai benih, atau kelompok penangkar benih. Salah satu perusahaan yang memproduksi benih padi bersertifikat adalah PT. Pertani (Persero). Perusahaan ini merupakan salah satu BUMN penyedia benih padi bersertifikat. PT. Pertani (Persero) tersebar di beberapa wilayah di Indonesia salah satunya terdapat di Provinsi Bali yang berlokasi di Banjar Pemaron, Desa Munggu, Kecamatan Mengwi, Kabupaten Badung dan Jalan Hayam Wuruk No. 76 Denpasar.

Sebagai salah satu perusahaan perbenihan di Indonesia PT Pertani (Persero) melaksanakan berbagai kegiatan dalam rangka memenuhi kebutuhan benih mulai dari produksi hingga pemasaran benih. Kegiatan produksi benih dilakukan di Desa Munggu, Kecamatan Mengwi, Kabupaten Badung, dan pemasaran benih dilakukan di cabang pemasaran yakni berlokasi di Jalan Hayam Wuruk No. 76 Denpasar. Kegiatan produksi dan pemasaran merupakan ujung tombak keberhasilan dan kesuksesan suatu perusahaan.

Jadi untuk memenuhi kebutuhan benih padi di Provinsi Bali, PT Pertani (Persero) Cabang Bali dengan kedua unit usahanya harus mampu berperan maksimal, oleh karena itu perlu dilakukan manajemen produksi untuk melakukan perencanaan hingga pengawasan produksi, sertifikasi benih untuk menjamin kualitas benih, serta manajemen pemasaran untuk memperluas pasar dan saluran distribusi agar benih dapat dipasarkan dengan baik hingga sampai di tangan konsumen. Berdasarkan uraian di atas, maka penulis tertarik untuk melakukan penelitian pada PT. Pertani (Persero) Cabang Bali mengenai manajemen produksi, sertifikasi, dan pemasaran benih padi bersertifikat.

\subsection{Rumusan Masalah}

Berdasarkan uraian latar belakang diatas, maka dapat dirumuskan suatu masalah sebagai berikut :

1. Bagaimana penerapan manajemen produksi benih padi pada PT. PERTANI (Persero) Cabang Bali ?

2. Bagaimana pemasaran benih padi yang dilakukan PT. PERTANI (Persero) Cabang Bali ?

\subsection{Tujuan Penelitian}

Berdasarkan uraian dari latar belakang masalah diatas, tujuan dari penelitian ini adalah:

1. Untuk mengetahui penerapan manajemen produksi pada PT. PERTANI (Persero) Cabang Bali. 
2. Untuk mengetahui kegiatan pemasaran benih padi pada PT. PERTANI (Persero) Cabang Bali.

\section{Metode Penelitian}

\subsection{Lokasi dan Waktu Penelitian}

Penelitian ini dilakukan di PT. PERTANI (Persero) Cabang Pemasaran Bali yang beralamat di Jalan. Hayam Wuruk No. 36/76, Denpasar. Bagian Produksi Benih Padi PT. PERTANI (Persero) Cabang Bali yang dikenal sebagai Unit Produksi Benih (UPB) Munggu yang berlokasi di Br. Pemaron Desa Munggu, Kecamatan Mengwi, Kabupaten Badung, dan Balai Pengawasan dan Sertifikasi Benih Tanaman Pangan di Jalan Raya Sesetan KM. 7, Denpasar-Bali. Penelitian ini dilaksanakan selama 4 bulan terhitung dari bulan Maret sampai dengan Juli 2017.

\subsection{Data}

Berdasarkan sumber data yang diperlukan dalam penelitian ini adalah data primer dan data sekunder. Data primer yang diperlukan berupa data yang diperoleh secara langsung dari PT. PERTANI (Persero) Cabang Bali seperti visi dan misi perusahaan, data jenis usaha, data jumlah produksi, tahap dan prosedur sertifikasi, dan data pemasaran serta penjualan benih padi. Data sekunder dari penelitian ini yaitu data yang diperoleh dari perusahaan atau instansi, dinas pemerintah, serta berbagai literatur yang berhubungan dari penelitian ini.

\subsection{Informan Kunci Penelitian}

Responden dari penelitian ini merupakan informan kunci yang dipilih karena lebih mengetahui permasalahan yang diteliti berdasarkan tugas dan tanggung jawabnya dalam perusahaan dan kaitannya dengan manajemen produksi, sertifikasi, serta pemasaran benih padi. Adapun informan kunci pada penelitian ini adalah Pimpinan PT. PERTANI (Persero) Cabang Pemasaran Bali, Pimpinan Unit Produksi Benih (UPB) Munggu yaitu, staff PT. PERTANI (Persero) Cabang Bali, para pekerja yang terkait dalam bidang produksi dan pemasaran benih padi PT. PERTANI (Persero) Cabang Bali, dan Kepala Bagian sertifikasi UPT. BPSBTP Provinsi Bali.

\subsection{Pengumpulan Data}

Pengumpulan data dalam penelitian ini dilakukan dengan beberapa cara diantaranya dengan metode observasi yakni dengan mengunjungi serta mengamati secara langsung lokasi penelitian dengan harapan dapat memperoleh gambaran yang jelas tentang implementasi dari kegiatan perusahaan, wawancara dengan pihak manajemen PT. PERTANI (Persero) baik itu di UPB Munggu maupun Cabang Pemasaran yang merupakan salah satu bentuk kominikasi verbal yang dilakukan dengan tanya jawab secara langsung untuk memperoleh informasi yang terkait dengan penelitian ini, dan dokumentasi dengan cara melihat serta mencatat dokumen 
maupun catatan yang berhubungan dengan penelitian, dan mengambil foto yang diambil secara langsung di lapangan.

\subsection{Metode Analisis Data}

Pada penelitian ini data yang diperoleh dianalisis dengan menggunakan metode deskriptif kualitatif. Analisis kualitatif bertujuan untuk menganalisis manajemen produksi yang diterapkan PT. PERTANI (Persero) Cabang Bali, tahapan produksi benih padi, dan pemasaran benih padi pada PT. PERTANI (Persero) Cabang Bali. Data yang sudah dikumpulkan kemudian dijabarkan sehingga dapat menghasilkan suatu kesimpulan.

\section{Hasil dan Pembahasan}

\subsection{Manajemen Produksi Benih Padi di PT. PERTANI (Persero) Cabang Bali}

PT. PERTANI (Persero) adalah salah satu perusahaan Badan Usaha Milik Negara (BUMN) yang bergerak dalam bidang produksi dan pemasaran benih padi serta satu-satunya produsen benih padi yang mempunyai kapasitas produksi cukup tinggi di Provinsi Bali. Benih padi yang diproduksi oleh PT. PERTANI (Pesrsero) terdiri dari enam jenis varietas yaitu ciherang, cigeulis, IR 64, towuti, Inpari 30, dan situbangendit. PT. PERTANI (Persero) Cabang Bali dalam menjalankan usahanya berdasarkan pengamatan, telah menerapkan fungsi manajemen yang terdiri dari perencanaan, pengorganisasian, pengawasan, dan evaluasi pada proses produksi benih padi.

\subsubsection{Perencanaan dalam proses produksi}

Kegiatan produksi benih padi pada Unit Produksi Benih (UPB) Munggu PT. PERTANI (Persero) dalam satu tahun telah diatur dalam Rencana Kerja dan Anggaran Perusahaan (RKAP). RKAP PT. PERTANI (Persero) di Provinsi Bali disampaikan oleh Cabang Pemasaran PT. PERTANI (Persero) Provinsi Bali ke Wilayah Jawa Timur di Surabaya dan Wilayah Pemasaran akan menyampaikan ke Kantor PT. PERTANI (Pusat). Apabila RKAP telah dibuat dan disetujui oleh pihak pusat maka Unit Produksi Benih (UPB) Munggu PT. PERTANI (Persero) Cabang Bali dapat mengetahui varietas benih apa yang dihasilkan pada tahun berikutnya, berapa jumlah produksi dari varietas tersebut dan berapa biaya yang dibutuhkan, kemudian pihak PT. PERTANI (Persero) Cabang Bali mengadakan pertemuan dengan kelompok tani untuk diajak bekerjasama dalam penangkaran benih padi. Apabila petani tersebut sudah bersedia untuk bermitra sebagai penangkar, pihak PT. PERTANI (Persero) akan bertanya kepada masing-masing kelompok tani berapa jumlah anggota, dan luas lahan yang dimiliki oleh kelompok tani tersebut, dengan adanya kesepakatan antara kelompok tani dan PT. PERTANI (Persero) Cabang Bali, barulah dirundingkan varietas apa yang cocok untuk ditanami pada lahan persawahan yang dimiliki oleh suatu kelompok tani. 
Benih yang diproduksi oleh PT. PERTANI (Persero) Cabang Bali bersama 19 kelompok tani yang ada di Denpasar, Tabanan, Jembrana, Gianyar, dan Badung adalah benih padi bersertifikat. Berdasarkan kesepakatan tersebut pihak PT. PERTANI (Persero) Cabang Bali mengajukan permohonan kepada Balai Pengawasan dan Sertifikasi Benih Tanaman Pangan. Pengajuan permohonan tersebut berupa sebuah formulir yang telah ditentukan oleh BPSBTP Provinsi Bali.

Pengajuan permohonan yang diajukan oleh PT. PERTANI (Persero) Cabang Bali yang sudah sampai di Balai Pengawasan dan Sertifikasi Benih Tanaman Pangan (BPSBTP), maka pihak BPSBTP akan melakukan pemeriksaan dokumen yang telah diberikan atau dicantumkan dalam permohonan sertifikasi berupa sket lapangan dengan keadaan yang ada di lapangan. Pengambilan contoh benih dari suatu kelompok benih untuk uji laboratorium akan diambil oleh Pengawas Benih Tanaman Pangan pada saat PT. PERTANI (Persero) Cabang Bali telah mengajukan surat permohonan pengambilan calon benih. Contoh benih tersebut telah dibuat dalam satu kemasan yang disegel oleh PT. PERTANI (Persero) Cabang Bali. Apabila hasil dari petugas uji laboratorium keluar dan menunjukan kelulusan pada kelas benih yang diajukan, maka petugas BPSBTP Provinsi Bali mengeluarkan surat rekomendasi yang ditujukan kepada PT. PERTANI (Persero) Cabang Bali, setelah surat diterima maka PT. PERTANI (Persero) mengajukan permohonan nomor induk ke BPSBTP untuk dicantumkan pada label benih, selanjutnya apabila label benih telah didapatkan, maka PT. PERTANI (Persero) dapat mencetak label benih yang diperlukan untuk setiap kemasan benih. BPSBTP akan melegalisir label yang dicetak PT. PERTANI (Persero) sebelum label ditempel pada kemasan. Benih yang telah memiliki label bersertifikat tersebut adalah benih yang dipasarkan oleh PT. PERTANI (Persero) Cabang Pemasaran dan tetap pada Pengawas Benih Tanaman selama berada di pasar.

\subsubsection{Tahap Produksi Benih Padi PT. PERTANI (Persero) Cabang Bali}

PT. PERTANI (Persero) merupakan perusahaan yang bergerak dibidang agribisnis yang memproduksi benih padi unggul bersertifikat. Dimana dalam memproduksi benih tersebut tentunya melalui tahapan produksi terlebih dahulu sebelum benih padi dipasarkan. Untuk dapat memahami tahapan produksi benih padi dapat dilihat pada gambar 1 .

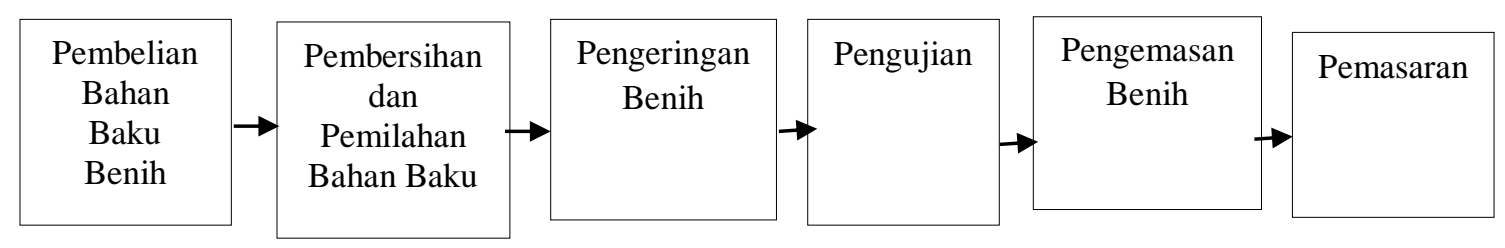

Gambar 1. Tahap Produksi Benih Padi 
Gambar 1 diatas dapat dilihat, proses awal dari tahapan produksi benih padi di PT. PERTANI (Persero) yaitu pembelian bahan baku yang diperoleh dari petani penangkar yang telah sepakat untuk bekerja sama dengan PT. PERTANI (Persero). Bahan baku tersebut adalah hasil panen dari sawah yang disebut dengan Calon Benih Kering Sawah (CBKS), selanjutnya CBKS akan dijemur dilandasan jemur yang sudah ada di Unit Produksi Benih Munggu. Proses penjemuran dilakukan dari pukul 08.00-16.00 WITA apabila cuaca sedang cerah, dengan ketebalan $4 \mathrm{~cm}$ sampai $5 \mathrm{~cm}$ diatas permukaan landasan jemur. Proses pengeringan ini dilakukan untuk mengurangi kadar air dari CBKS. Pengeringan dilaksanakan hingga kadar air CBKS maksimal 12-13\%. Jumlah CBKS yang telah dikeringkan akan menyusut karena adanya pengurangan kadar air, dan CBKS akan berubah nama menjadi Calon Benih Kering Kotor (CBKK). Tahap berikutnya adalah pembersihan dan pemilahan dengan menggunakan mesin blower. Jumlah CBKK yang telah melalui proses pembersihan dan pemilahan juga akan mengalami penyusutan dan akan berubah nama menjadi Calon Benih Kering Bersih (CBKS). Tahap selanjutnya adalah pengujian, proses pengujian terlebih dahulu dilakukan oleh pihak PT. PERTANI (Persero) yakni pengujian kadar air dengan menggunakan bantuan alat yang bernama Cera Tester dan pengujian daya berkecambah. Proses pengujian yang dilakukan oleh pihak UPB Munggu PT. PERTANI (Persero) telah selesai, barulah kemudian pengujian dilakukan oleh pihak BPSBTP. Benih yang telah lulus uji laboratorium dinamakan Benih Lulus Uji (BLU). Tahapan produksi selanjutnya adalah pengemasan benih. Proses pengemasan dilakukan menggunakan plastik berbahan polyprophylene. Benih yang telah dikemas disebut dengan Benih Bersih Dalam Kantong (BBDK). BBDK ini dikemas ke dalam plastik dengan berat isi $5 \mathrm{~kg}$ dan $10 \mathrm{~kg}$. BBDK yang telah dikemas inilah yang siap untuk dipasarkan atau dimutasi oleh Cabang Pemasaran Bali.

\subsubsection{Pengorganisasian dalam proses produksi benih padi di PT. PERTANI (Persero) Cabang Bali}

Berdasarkan wawancara dengan pimpinan UPB Munggu PT. PERTANI (Persero) pengorganisasian dalam kegiatan produksi benih padi dilakukan oleh team yang telah disesuaikan dengan tugas dan wewenangnya masing-masing. Team tersebut terdiri dari bendahara materiil, bendahara operasional lapangan, bendahara finansial, dan bendahara operator.

\subsubsection{Pengawasan dalam kegiatan produksi pada PT. PERTANI (Persero) Cabang Bali}

Kegiatan produksi benih padi di UPB Munggu PT. PERTANI (Persero) Cabang Bali pada setiap langkah sangat perlu untuk diawasi dan diperhatikan. Proses pengawasan produksi dilakukan setiap hari oleh pimpinan UPB Munggu yang dibantu oleh team serta seluruh pekerja yang terlibat dalam kegiatan produksi mulai dari melakukan pertemuan dengan kelompok tani, pemeriksaan lapangan, pembelian 
bahan baku, penegeringan, pembersihan, pengujian, hingga pengemasan benih yang siap untuk dipasarkan. Pimpinan UPB Munggu sudah memberikan tugas dan tanggung jawab oleh semua team, pengawasan pada kegiatan produksi juga dilakukan oleh pekerja yang ada di pabrik maupun gudang, karena pekerjaan dalam proses produksi ini merupakan pekerjaan yang dilakukan dengan sifat kebersamaan.

\subsubsection{Evaluasi pada kegiatan produksi benih padi di PT. PERTANI (Persero) Cabang Bali}

Berdasarkan wawancara dengan pimpinan UPB Munggu, evaluasi dilakukan setiap tiga bulan sekali. Seluruh Unit Produksi (UPB) yang berada dibawah naungan wilayah Jawa Timur dievaluasi mulai dari jumlah produksi, harga pokok, dan biaya yang ditimbulkan dalam seluruh kegiatan produksi benih, serta kualitas benih yang diproduksi.

\subsection{Internal Quality Control}

Internal Quality Control pada dasarnya mengacu pada kegiatan sertifikasi oleh BPSBTP Provinsi Bali. Beberapa tujuan Internal Quality Control ini adalah untuk menjaga kualitas hasil produksi, untuk mendapatkan kelulusan dari setiap hasil pemeriksaan sertifikasi, membina petani penangkar, dan untuk menjaga eksistensi PT. PERTANI (Persero) sebagai produsen benih padi bersertifikat. Internal Quality Control dilakukan sebelum Pengawas Benih Tanaman Pangan melakukan tahapan demi tahapan sertifikasi.

\subsection{Pemasaran Benih Padi pada PT. PERTANI (Persero) Cabang Bali}

PT. PERTANI (Persero) adalah perusahaan BUMN yang memproduksi benih padi bersertifikat. Kegiatan pemasaran benih padi di PT PERTANI Persero Cabang Bali dilakukan oleh Cabang Pemasaran Bali. Kantor Cabang Pemasaran Bali PT. PERTANI (Persero) berlokasi di Jalan Hayam Wuruk No. 76 Denpasar. Berdasarkan data yang berasal dari PT. PERTANI (Persero) Cabang Pemasaran Bali, bahwa target dan penjualan benih padi pada tahun 2012-2016 adalah sebagai berikut :

Tabel 1.

Target dan penjualan Benih Padi PT. PERTANI (Persero) Cabang Bali

Tahun 2012-2016

\begin{tabular}{|c|c|c|c|}
\hline Tahun & Target $(\mathrm{kg})$ & Penjualan $(\mathrm{kg})$ & Realisasi $(\%)$ \\
\hline 2012 & 1.000 .000 & 850.955 & $85,09 \%$ \\
\hline 2013 & 1.100 .000 & 1.013 .893 & $92,17 \%$ \\
\hline 2014 & 1.250 .000 & 1.345 .265 & $107,62 \%$ \\
\hline 2015 & 1.250 .000 & 1.541 .472 & $123,31 \%$ \\
\hline 2016 & 1.500 .000 & 1.050 .467 & $70,03 \%$ \\
\hline Rata-rata & 1.220 .000 & 850.955 & $95,64 \%$ \\
\hline
\end{tabular}

Sumber : PT. PERTANI (Persero) Cabang Pemasaran Bali (2016) 
Pada Tabel 1 diatas menunjukkan bahwa realisasi penjualan dari target yang dibebankan secara umum mencapai 95,64 \%. Pada tahun 2012 hingga tahun 2015 relaisasi penjualan mencapai target sebesar $123,31 \%$. Pencapaian target pada tahun 2012 hingga tahun 2015 tersebut disebabkan oleh banyaknya proyek pemerintah dan tingginya modal yang diberikan oleh pihak PT. PERTANI (Persero) Pusat. Ini menunjukan bahwa permintaan konsumen terhadap benih padi dari produksi PT. PERTANI (Persero) Cabang Bali cukup tinggi . Pada tahun 2016 realisasi penjualan benih padi menurun sebesar 70,03\%. Hal tersebut menunjukan realisasi penjualan tidak mencapai target yang ditentukan. Menurunnya realisasi penjualan benih padi pada tahun 2016 disebabkan karena terlambatnya modal yang diberikan oleh pihak pusat sehingga pihak PT. PERTANI (Persero) Cabang Bali mengalami kesulitan untuk membeli calon benih dari petani. Adapun upaya yang dilakukan oleh PT. PERTANI (Persero) Cabang Bali untuk meningkatkan penjualan yaitu melobi pemerintah untuk mempercayakan proyeknya ke PT. PERTANI (Persero) Cabang Bali, kemudian upaya lainnya juga lebih meningkatkan mutu benih dengan begitu petani lebih percaya dengan PT. PERTANI (Persero) sebagai produsen benih padi bersertifikat yang memiliki kualitas baik.

\subsubsection{Strategi Pemasaran Benih Padi PT. PERTANI (Persero) Cabang Bali}

Strategi pemasaran erat kaitannya dengan bauran pemasaran atau marketing mix. Menurut Kotler (2000), bauran pemasaran adalah alat pemasaran yang digunakan untuk mencapai tujuan pemasaran di pasar sasaran yang meliputi item alat pemasaran yaitu product, price, promotion, dan place (4P). PT. PERTANI (Persero) Cabang Bali menerapkan item bauran pemasaran atau marketing mix (4P) dalam memasarkan benihnya. Adapun item bauran pemasaran atau marketing mix (4P) yang diterapkan oleh PT. PERTANI (Persero) yaitu :

1. Produk (product)

Produk yang diproduksi oleh PT. PERTANI (Persero) adalah benih padi bersertifikat. Terdapat enam jenis varietas benih yang dipasarkan yaitu varietas Ciherang, Cigeulis, IR 64, Towuti, Inpari 30, dan Situbagendit. Mutu benih yang dipasarkan harus sesuai dengan varietasnya dan terjamin mutunya, serta sudah tersertifikasi oleh Balai Pengawasan dan Sertifikasi Banih Tanaman Pangan (BPSBTP) yang ditandai dengan pemasangan label.

2. Harga (price)

Harga benih yang dipasarkan harus seimbang antara kualitas benih dan daya beli konsumen, dimana harga benih pervarietas berkisar antara Rp. 9.500 sampai Rp. $10.500 / \mathrm{kg}$.

3. Lokasi (place)

Benih padi yang akan dipasarkan harus sesuai dengan musim tanam dan sesuai dengan waktu yang diminta oleh konsumen, serta harus diantarkan ke lokasi yang sesuai dengan permintaan pasar dan tepat pada waktunya. Benih padi yang 
diproduksi PT. PERTANI (Persero) Cabang Bali dipasarkan ke seluruh Kabupaten yang ada di Provinsi Bali.

4. Promosi (promotion)

Promosi yang dilakukan oleh pihak PT. PERTANI (Persero) dalam memasarkan benihnya yaitu dengan menggunakan media online berupa pembentukan website perusahaan yang dapat diakses oleh konsumen, dan pihak PT. PERTANI (Persero) melakukan pendekatan yakni mengikuti tender dari pemerintah untuk mendapatkan suatu proyek.

\section{Kesimpulan dan Saran}

\subsection{Kesimpulan}

Fungsi Manajemen dalam kegiatan produksi benih padi di PT. PERTANI (Persero) Cabang Bali sudah berjalan dengan baik. Pada fungsi perencanaan, proses produksi pada Unit Produksi Benih (UPB) Munggu telah diatur dalam Rencana Anggaran Kerja Perusahaan (RKAP). Fungsi pengorganisasian pengalokasian sumber daya yang ada sudah diatur dalam struktur organisasi yang jelas. Pada fungsi pengawasan, proses pengawasan dalam kegiatan produksi dilakukan setiap hari oleh pimpinan Unit Produksi Benih (UPB) Munggu dan dibantu oleh team yakni bendahara materiil, finansial, dan operasional lapangan. Pada tahap evaluasi dilakukan setiap 3 bulan sekali yang dilihat dari jumlah produksi, harga pokok benih, serta kualitas benih yang diproduksi. Proses pemasaran benih padi di PT. PERTANI (Persero) Cabang Bali menggunakan dua sistem pemasaran yaitu sistem pemasaran Free Market dan sistem pemasaran Public Service Obligation. PT. PERTANI (Persero) Cabang Bali dalam memasarkan benihnya menerapkan item bauran pemasaran yang terdiri dari 4P yaitu produk (product), lokasi (place), harga (price), dan promosi (promotion).

\subsection{Saran}

Saran yang dapat diberikan yaitu 1) Diharapkan PT. PERTANI (Persero) Pusat tepat waktu memberikan modalnya agar proses produksi tidak mengalami suatu hambatan dan proses produksi bisa berjalan lebih baik lagi, 2) Diharapkan PT. PERTANI (Persero) Cabang Pemasaran Bali dapat menekankan strategi pemasaran berupa promosi sebgagai upaya untuk meningkatkan penjualan benih padi, dan 3) Diharapkan PT. PERTANI (Persero) Cabang Bali lebih mendekatkan diri dengan pemerintah agar selalu dipercaya untuk mengemban suatu proyek dan dapat meningkatkan penjualan setiap tahunnya.

\section{Ucapan Terimakasih}

Ucapan terimakasih ini penulis tujukan kepada PT. PERTANI (Persero) Unit Produksi Benih Munggu serta Cabang Pemasaran Bali serta semua pihak yang telah membantu dalam pelaksanaan penelitian hingga karya ilmiah ini dapat dipublikasikan di e-jurnal. 


\section{Daftar Pustaka}

Ance, G.K. 2003. Teknologi Benih Pengolahan Benih dan Tuntunan Praktikum. Jakarta.

Arsanti, Idha Widi. 1995. Analisis Produksi dan Strategi Pemasaran Benih (Study Kasus pada Perum Sang Hyang Seri, Cabang Jateng dan DIY, UPB Klaten II). Jurusan Sosial Ekonomi Pertanian, Fakultas Pertanian, Institut Pertanian Bogor. Bogor.

Assauri, Sofjan. 1987. Manajemen Pemasaran. Penerbit CV Rjawali. Jakarta Utara

Assauri, Sofjan. 1998. Edisi Revisi Manajemen Produksi dan Operasi. Lembaga Penerbit Fakultas Ekonomi Universitas Indonesia. Jakarta

Badan Pusat Statistik Provinsi Bali. 2015. Bali dalam Angka

Deliyanti Oentoro. 2012. Manajemen Pemasaran Modern. Yogyakarta. LakBang PRESSindo

Direktorat Jenderal Tanaman Pangan, Direktorat Jenderal Hortikultura. 2006. Pedoman Laboratorium Pengujian Mutu Benih Tanaman Pangan dan Hortikultura. Departemen Pertanian. Jakarta.

Dinas Pertanian Tanaman Pangan Provinsi Bali. 2009. Visi dan Misi Distanpan Provinsi Bali. Denpasar.

Kotler, Philip dan K.K. Lane. 2008. Manajemen Pemasaran Edisi Ketiga Belas. Jakarta.

Kotler, Philip dan Gary Amstrong. 1997. Dasar-dasar Pemasaran. Edisi Keenam Jilid 1.Terjemahan. Intermedia. Jakarta

Lita,S. 2010. Edisi Revisi Teknologi Banih. Jakarta. PT. Pertani (Persero). 2003. Company Profile. Jakarta.

Qamara, W., dan Asep. 1990. Pengantar Produksi Benih. Jakarta.

Sugiyono. 2012. Metode Penelitian Kuantitatif Kualitatif dan R\&B. ALFABETA. Bandung.

Sujarweni, Wiratna V. 2014.Metodologi Penelitian. Yogyakarta : Pustaka Baru Press. 